DR KAYT DAVIES is a senior lecturer in journalism at Edith Cowan University, Perth.

\section{A global evolution in risk reporting}

International News Reporting: Frontlines and Deadlines, edited by John Owen and Heather Purdey. London: Wiley Blackwell, 2008, 280 pp. ISBN 978140-5160-38-4.

OOKING around a lecture thea-
tre of students majoring in journalism in an Australian university, it may seem fair enough to ask how important it is to teach them about war reporting. How many of these music, fashion and sport-inspired kids are going to find themselves on a frontline?

Reading through Owen and Purdey's book two rationales emerge. The first is that the era of battle-weary foreign correspondents is waning. To a growing extent wars and natural disasters are being reported by locals, and that means our international students who will be heading home to less stable political environments than our own, need to be prepared.

\section{International News Reporting}

Frontlines and Deadlines

This book shows there can be no substitute

or first-hand reporting from the field.

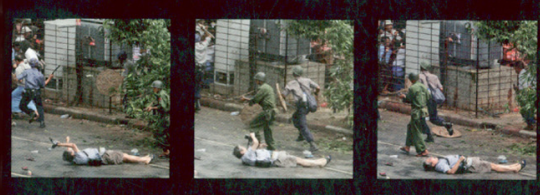

Edited by

John Owen and Heather Purdey

\section{(3)WILEY-BLACKWELL}

The world could well get less stable and no amount of technology can tell the story if there are not journalists who can keep their heads about them enough to use it.

The second is that the book brings home the importance of our profession's reputation for being unbiased. In a cultural studies context it can seem naive to claim a freedom from bias, but when a soldier has you at gunpoint and he is wondering whose side you are on, it is handy if he is familiar with the idea of the press being neutral observers, not spies and not spin merchants. This concept 
unites all journalists, no matter how safe and domestic their beats, in the common mission of keeping the war reporters safe by living by the principle of neutrality and letting everyone we meet know that journalists are, by nature, impartial.

The book offers 14 chapters, written by contributors specifically chosen for their hands-on involvement with the issue their chapter deals with. Each chapter is prefaced with an introduction by John Owen, who is currently the acting executive producer of programmes for the Americas for the Al Jazeera English channel. He is with Al Jazeera on a sabbatical from City University in London where he is professor of international journalism. The introductions are tidy, wellreferenced essays that introduce the contributors and string the chapters together into a coherent narrative clearly relevant to the education of young journalists.

The chapters themselves take a level-headed approach to the psychological challenges inherent in frontline reporting. Janine di Giovanni kicks off with a discussion about bearing witness. She talks about having seen more bodies than she can count, about having to think fast at gunpoint and about how having a baby changed the way she thinks and acts in these circumstances. It's a humble, frank, human interest opening to the book that sets the tone of inclusiveness and invites readers into the global journalism family.

The next two chapters provide an excellent summary of the evolution of the global news industry over the past few decades. They cover the corporate takeovers that resulted in the current configuration of media empires, including Reuters, AP and AFP, as well as the specific technological leaps that have changed the way the business is done. In providing an insight into the work done by agency journalists the book shines a light on a career path many students don't consider, simply because agency staff are less visible than masthead and broadcaster employed journalists.

Chapter 10, Taking the Right Risk, seems particularly relevant in the wake of the recent revival in interest in events that occurred in Balibo in 1975. It outlines the evolution of safety management in news organisations over the past 20 years. Written by former vice-president and managing editor of CNN Chris Cramer-now a champion of safety training and trauma counselling-it grasps the journalist's dilemma by the throat. He talks about being told to leave Dubrovnik in October 1991, and being furious that his competitors were going to stay and produce remarkable coverage. 
Then comes the epiphany and the evolution of a new way of thinking about risk and reporting that students who may find themselves in harm's way, or who may become editors with journalists in the field, should be taught during their courses.

The following chapter is about emotions and trauma and the way post traumatic stress disorder, if left unrecognised and untreated, can skew reporting and mess with the personal lives of journalists. This chapter challenges the wisdom of the old 'suck it up, knock back some whisky, chain smoke and get on with the next story' approach of the old-school journalists. It talks about the approach to trauma being taken in the world's biggest and best newsrooms, in a way that 'isn't about becoming all touchy feely, weeping over your screen or your copy or reporting only good news'.

It is about being aware of the process of trauma so that journalists interviewing people who have just experienced horrific events that could be war-related or traffic-related, can understand them, and tell their stories with authenticity and compassion.

In telling their stories, the contributors not only offer a master-class in journalism, they also talk about the hotspots and wars that their stories were set in. Our younger tertiary students were babies when the first
Gulf War began and unless they have studied history many of them have a scanty grasp on world affairs over the past few decades. This makes the history lessons embedded in the book an added bonus.

The way the contributors focus optimistically on the future of journalism is the other bonus. The book is compelling, hard hitting and it clearly outlines why good journalism is, and will always be, important. 